\title{
Rancangan Strategi Pemasaran Media Sosial Menggunakan Model SOSTAC
}

\author{
Yoga Aditya Pranata*, Reni Amaranti \\ Prodi Teknik Industri, Fakultas Teknik, Universitas Islam Bandung, \\ Indonesia. \\ *yogaadityapranata7@gmail.com,reniamaranti2709@gmail.com
}

\begin{abstract}
PT. X is a manufacturer of motorcycle accessories and parts. The company's social media is currently not optimal and left behind by competitors so that product sales do not reach the marketing target of brand awareness for SND Racing products, considering that social media is the marketing and promotion channel with the most users on the internet. This study aims to design a social media marketing strategy to increase brand awareness of SND Racing products with the scope of research from September 2012 to February 2021. The design of social media marketing strategies is carried out on the Facebook and Instagram platforms using the SOSTAC model. The performance of the social media marketing strategy design as measured using Keyhole.co analytics to find out the most frequent post types, the most interesting post types, optimal delivery times, best delivery times, optimal post lengths, hashtags based on interactions, and optimal hashtags to use as the basis for the proposal effective social media marketing strategy design. social media marketing strategy can provide a significant difference in increasing brand awareness compared to the previous year, as evidenced by the Wilcoxon signed-rank test hypothesis because $\mathrm{H} 0$ is rejected (Tcount (1) > Ttable $(0))$.
\end{abstract}

Keywords: Social Media Marketing, SOSTAC Model, Keyhole.co.

\begin{abstract}
Abstrak. PT. X merupakan produsen aksesoris dan onderdil motor. Pemasaran media sosial perusahaan saat ini belum optimal dan tertinggal oleh kompetitor sehingga penjualan produk tidak mencapai target dikarenakan kesadaran merek untuk produk SND Racing masih rendah mengingat media sosial adalah saluran pemasaran dan promosi dengan pengguna terbanyak di internet. Penelitian ini bertujuan untuk merancang strategi pemasaran media sosial untuk meningkatkan kesadaran merek produk SND Racing dengan ruang lingkup penelitian pada bulan September 20120 sampai bulan Februari 2021. Perancangan strategi pemasaran media sosial dilakukan pada platform Facebook dan Instagram menggunakan model SOSTAC. Performa rancangan strategi pemasaran media sosial diukur menggunakan analitik Keyhole.co untuk mengetahui tipe kiriman paling sering, tipe kiriman paling menarik, waktu kirim optimal, waktu kirim terbaik, panjang kiriman optimal, tagar teratas berdasarkan keterlibatan, dan tagar optimal yang akan digunakan sebagai dasar usulan rancangan strategi pemasaran media sosial efektif. Rancangan strategi pemasaran media sosial dapat memberikan perbedaan signifikan terhadap peningkatan kesadaran merek dibandingkan tahun sebelumnya, dibuktikan oleh uji hipotesis Wilcoxon signed-rank test dikarenakan H0 ditolak (Thitung (1) > Ttabel (0)).
\end{abstract}

Kata Kunci: Pemasaran Media Sosial, Model SOSTAC, Keyhole.co. 


\section{A. Pendahuluan}

Perkembangan pengunaan internet juga memiliki pengaruh yang besar dalam sektor ekonomi khususnya dalam hal pemasaran dikarenanakan munculnya tren jual beli di internet atau pemasaran internet yang disebut pemasaran digital. Badan Pusat Statistik (2019) mengungkapkan bahwa jumlah pengguna internet di Indonesia mencapai 168.3 juta pada tahun 2019 dari berbagai sektor, salah satunya adalah sektor otomotif. Peningkatan tren pada minat sektor otomotif ditandai dengan meningkatnya minat pada kategori mobil sebesar $147 \%$ dan kategori motor sebesar $172 \%$. Berdasarkan tren penggunaan internet disektor otomotif dan aktifitas pelanggan di internet dapat diperkirakan PT. X sebagai perusahaan aksesoris dan onderdil motor memiliki peluang yang menjanjikan apabila menggunakan strategi pemasaran media sosial untuk melakukan penjualan produk dengan merek SND Racing di platform media sosial. Pendapatan perusahaan pada tahun 2020 masih belum memenuhi target pendapatan yang ditetapkan. Strategi pemasaran yang digunakan perusahaan masih terbilang konvensional atau belum menggunakan pemasaran media sosial efektif untuk memasarkan produk SND Racing di platform media sosial. Ditinjau dari kondisi perusahaan saat ini, perusahaan perlu menggunakan pemasaran media sosial dikarenakan memiliki keunggulan dibandingkan pemasaran konvensional. Namun apabila perusahaan tetap mempertahankan strategi pemasaran saat ini, maka perusahaan akan semakin tertinggal dengan perusahaan kompetitor yang sudah menggunakan pemasaran digital untuk pemasaran di internet mengingat tren penggunaan internet untuk aktivitas jual beli, tentunya hal ini akan berpengaruh pada profit yang didapat oleh perusahaan. Penelitian rancangan strategi pemasaran media sosial dilatar belakangi oleh cara merancang strategi pemasaran media sosial efektif berdasarkan faktor-faktor yang mempengaruhi kesadaran merek produk SND Racing sehingga dapat memberi perbedaan peningkatan kesadaran merek produk SND Racing. Rancangan strategi pemasaran media sosial bertujuan untuk merumuskan strategi pemasaran media sosial efektif menggunakan model SOSTAC dan membuktikan peningkatan kesadaran menggunakan uji hipotesis Wilcoxon signed-rank test yang kemudian performa rancangan strategi pemasaran media sosial dianalisis menggunakan aplikasi Keyhole.co untuk mengetahui faktor yang mempengaruhi kesadaran merek produk SND Racing dan membuat usulan dari analisis faktor-faktor tersebut.

\section{B. Metodologi Penelitian}

Penelitian rancangan strategi pemasaran media sosial menggunakan model SOSTAC merupakan penelitian kualitatif yang bersifat deskriptif dan bertujuan mengidentifikasi permasalahan saat ini di perusahaan dalam bentuk kata-kata dan bahasa dengan memanfaatkan metode ilmiah melalui pengumpulan data yang berfokus kepada kualitas data dibandingkan kuantitas data dan hanya memaparkan situasi atau peristiwa sehingga tidak perlu mencari atau menjelaskan hubungan dan tidak menguji hipotesis. Dalam penelitian kualitatif peneliti berperan sebagai perencana, pengumpul data, analisis penafsiran data dan pelapor hasil penelitian. Instrumen selain manusia seperti observasi dan pedoman wawancara namun dengan fungsi terbatas pada pendukung data penelitian. Peneliti memiliki posisi kunci penelitian dikarenakan keberadaan pada objek penelitian merupakan hal wajib sehingga dapat menjamin tingkat keakuratan data. Subjek penelitian terdiri dari manajer pemasaran, admin media sosial, dan admin marketplace dengan penetapan profil umum terdiri dari satu spesialis pemasaran media sosial. Penelitian bertujuan untuk membuat rancangan strategi dan pengelolaan pemasaran media sosial efektif menggunakan model SOSTAC, selain itu bertujuan untuk mengetahui pendapatan dan biaya yang didapat dan dikelaurkan perusahaan pada saat penerapan strategi pemasaran media sosial selama enam bulan dari bulan September 2020 sampai bulan Februari 2021 dan membuktikan adanya perbedaan keadaan sebelum penerapan staretgi dan setelah penerapan strategi dengan menggunakan uji hipoteis Wilcoxon signed-rank test. Model SOSTAC digunakan karena dapat melakukan analisis, merancang, dan mengukur strategi pemasaran media sosial yang digunakan dan dikaitkan dengan pemasaran riil.

Model SOSTAC sebagai model perancangan strategi pemasaran media sosial memudahkan untuk melakukan identifikasi seluruh hal utama yang dilakukan untuk mencapai tujuan perusahaan (Chafey, 2009). Tahapan model SOSTAC adalah sebagai berikut. 
1. Situation analysis.

2. Objectives.

3. Strategy

4. Tactics

5. Action

6. Control.

Pengembalian investasi pemasaran media sosial dilakukan menggunakan perhitungan return of investmen untuk mengetahui rasio yang menunjukkan kemampuan perusahaan untuk mendapatkan profit yang digunakan untuk menutupi investasi Sutrisno (2012). Faktor yang mempengaruhi pengembalian investasi terdiri perputaran aktiva yang digunakan untuk proses operasional dan profit operasional dari penjualan perusahaan.

Uji nonparametrik Wilcoxon signed-rank test dilakukan untuk membandingkan data berskala ordinal dengan jenis penelitian komparasi (perbandingan sebelum-sesudah) dari suatu kondisi (Siegel, 1997). Tahapan uji Wilcoxon signed-rank test adalah sebagai berikut.

1. Menentukan formulasi hipotesis.

2. Menentukan tarif uji signifikansi $(\alpha)$ dengan T tabelnya, pengujian dapat berbentuk satu atau dua sisi.

3. Menentukan kriteria pengujian dan daerah keputusan.

4. Menghitung dan menentukan uji nonparametrik Wilcoxon.

5. Menentukan daerah keputusan hipotesis.

6. Membuat kesimpulan.

\section{Hasil Penelitian dan Pembahasan}

Penelitian rancangan strategi pemasaran media sosial dilakukan di PT. X menggunakan model SOSTAC yang terdiri ari tahapan situation analysis, objectives, strategy, tactics, action, dan control yang bertujuan untuk mengukur performa strategi dan membuat usulan strategi berdasarkan analisis aplikasi Keyhole.co, serta mengetahui pengembalian investasi dari rancangan strategi pemasaran media sosial yang diterapkan dan diamati selama enam bulan dari bulan September 2020 sampai bulan Februari 2021. Pengumpulan data dilakukan dengan mengumpulkan data primer yang terdiri dari hasil observasi, hasil wawancara, dan hasil pengamatan aktivitas media sosial yang akan digunakan pada tahapan situation analysis dan objectives sedangkan data sekunder terdiri dari dokumen dan literatur yang akan digunakan sebagai pendukung penelitian. Tahapan ra

Situation analysis atau analisis situasi dilakukan untuk mengetahui situasi saat ini yang dengan mengidentifikasi costumer analysis, competitor analysis, dan digital SWOT analysis. Costumer analysis menentukan bahwa target pelanggan produk SND Racing menjadi persona pelanggan yang terdiri dari pria dengan rentan usia 18-44 tahun yang menggunakan platform media sosial Facebok dan Instagram, bengkel, took retail aksesoris dan onderdil motor dengan fokus daerah pemasaran kota Bandung, Bekasi, Jakarta, Surabaya, dan Yogyakarta. Competitor analysis menentukan bahwa perbandingan statistik media sosial SND Racing dan kompetitor yang terdiri dari TDR, BRT, dan BRT masih tertinggal dari aspek aktivitas, jumlah konten, dan jumlah pengikut media sosial sehingga dapat ebrdampak pada kesadaran merek secara digital. Digital SWOT analysis menentukan bahwa perusahaan harus memahami kekuatan, kelemahan, peluang, dan ancaman yang ada untuk meningkatkan nilai kompetitif digital perusahaan, analisis SWOT dapat dilihat pada Tabel 1.

Tabel 1. Analisis SWOT

\begin{tabular}{|l|l|l|}
\hline \multicolumn{1}{|c|}{ S-Strength } & \multicolumn{1}{|c|}{ W-Weakness } \\
\cline { 2 - 3 } & \multicolumn{1}{|c|}{$\bullet$ Merek sudah terdaftar. } & $\bullet$ Persepsi merek masih muda. \\
\cline { 2 - 3 } & $\bullet$ Produk bersertifikat SNI. & $\bullet$ Produk bisa digantikan merek lain. \\
\hline
\end{tabular}


Tabel 1. Analisis SWOT (Lanjutan)

\begin{tabular}{|c|c|c|}
\hline & S-Strength & W-Weakness \\
\hline & $\begin{array}{l}\text {-Memiliki produk motor SND } \\
\text { TMX. }\end{array}$ & $\begin{array}{l}\bullet \text { Varian produk lebih sedikit } \\
\text { dibanding kompetitor. }\end{array}$ \\
\hline & $\begin{array}{l}\text {-Memiliki tim balap SND Rapido } \\
\text { sebagai brand ambassador. }\end{array}$ & $\begin{array}{l}\bullet \text { Harga lebih mahal dibanding } \\
\text { kompetitor. }\end{array}$ \\
\hline & $\begin{array}{l}\text {-Menggunakan media sosial untuk } \\
\text { promosi. }\end{array}$ & $\begin{array}{l}\text {-Anggaran iklan media sosial } \\
\text { sedikit. }\end{array}$ \\
\hline & $\begin{array}{l}\text {-Lokasi strategis untuk distribusi } \\
\text { produk. }\end{array}$ & $\begin{array}{l}\text {-Pengikut media sosial lebih sedikit } \\
\text { disbanding kompetitor. }\end{array}$ \\
\hline & $\begin{array}{l}\text {-Showroom dengan tata letak } \\
\text { menarik dengan konsep otomotif. }\end{array}$ & $\begin{array}{l}\text {-Tidak memiliki pegawai ahli atau } \\
\text { tim pemasaran media sosial. }\end{array}$ \\
\hline & & $\begin{array}{l}\text {-Pengikut media sosial lebih sedikit } \\
\text { dibanding kompetitor. }\end{array}$ \\
\hline & & $\begin{array}{l}\text { - Tidak memiliki pegawai ahli atau } \\
\text { tim pemassran media sosial. }\end{array}$ \\
\hline O-Opportunities & SO Strategies & \begin{tabular}{|c|} 
WO Strategies \\
\end{tabular} \\
\hline $\begin{array}{l}\text {-Cross-selling platform media } \\
\text { sosial dan marketplace. }\end{array}$ & $\begin{array}{l}\text {-Melakukan data minning } \\
\text { pelanggan. }\end{array}$ & $\begin{array}{l}\bullet \text { Mengamati strategi pemasaran } \\
\text { media sosial kompetitor. }\end{array}$ \\
\hline $\begin{array}{l}\text {-Segmen pasar motor bebek dan } \\
\text { trail. }\end{array}$ & $\begin{array}{l}\text { - Menggunakan strategi pemasaran } \\
\text { media sosial. }\end{array}$ & $\begin{array}{l}\bullet \text { Merekrut pegawai ahli atau tim } \\
\text { pemasaran media sosial. }\end{array}$ \\
\hline $\begin{array}{l}\text {-Toko retail onderdil di kota-kota } \\
\text { besar. }\end{array}$ & $\begin{array}{l}\text { - Menggunakan fitur bisnis } \\
\text { marketplace. }\end{array}$ & $\begin{array}{l}\text { - Menggunakan strategi pemasaran } \\
\text { afiliasi. }\end{array}$ \\
\hline -Strategi pemasaran media sosial. & & $\begin{array}{l}\text {-Meningkatkan interaksi dengan } \\
\text { pelanggan di media sosial. }\end{array}$ \\
\hline \multicolumn{3}{|l|}{$\begin{array}{l}\text {-Perkembangan pengguna media } \\
\text { sosial. }\end{array}$} \\
\hline T-Threats & ST Strategies & WT Strategies \\
\hline -Pelanggan beralih ke kompetitor. & $\begin{array}{l}\text {-Memasarkan produk secara } \\
\text { digital. }\end{array}$ & $\begin{array}{l}\text {-Memberikan promo potongan } \\
\text { harga. }\end{array}$ \\
\hline $\begin{array}{l}\text {-Masuknya produk kompetitor ke } \\
\text { pasar. }\end{array}$ & $\begin{array}{l}\text { •Mempromosikan produk dengan } \\
\text { kerjasama influencer. }\end{array}$ & $\begin{array}{l}\text {-Meningkatkan anggaran iklan } \\
\text { media sosial. }\end{array}$ \\
\hline $\begin{array}{l}\text {-Kompetitor memiliki strategi } \\
\text { pemasaran media sosial yang lebih } \\
\text { baik. }\end{array}$ & & \\
\hline
\end{tabular}

Objectives atau tujuan dilakukan untuk menentukan tujuan tujuan realitstis perusahaan yang berfokus pada revenue (pendapatan), margin (keuntungan), statisfaction (kepuasan), dan brand value (nilai merek). Tujuan pemasaran media sosial dikategorikan menjadi $5 \mathrm{~S}$ dan ditargetkan selama enam bulan. Target dari sell adalah meningkatkan penjualan produk sebanak 600 produk pada platform marketplace. Tujuan serve adalah meningkatkan nilai ulasan pelanggan menjadi 4.5 pada plarform marketplace. Target speak adalah meningkatkan $50 \%$ jumlah pengikut media sosial. Target save adalah mengurangi anggaran iklan dan promsosi sebesar 20\%. Target Sizzle adalah meningkatkan jumlah engagement sebesar 24.000.

Strategy atau strategi dilakukan untuk menentukan rancangan strategi dengan tujuan untuk menentukan keputusan taktis pemasaran media sosial sehinga target perusahaan dapat terpenuhi. Strategi pemasaran media sosial dapat dilihat pada Tabel 2. 
Tabel 2. Strategi Pemasaran Media Sosial

\begin{tabular}{|c|l|l|l|}
\hline No & \multicolumn{1}{|c|}{ Aktivitas } & \multicolumn{1}{c|}{ Strategi } & \multicolumn{1}{c|}{ Deskripsi Strategi } \\
\hline \multirow{3}{*}{1} & $\begin{array}{l}\text { Mendefinisikan strategi } \\
\text { mendengarkan dan } \\
\text { reputasi. }\end{array}$ & $\begin{array}{l}\text { Memahami } \\
\text { penggunaan media } \\
\text { sosial. }\end{array}$ & Memahami pengikut media sosial. \\
\cline { 3 - 4 } & & Memahami aktivitas media sosial. \\
\cline { 3 - 4 } & &
\end{tabular}

Tabel 2. Strategi Pemasaran Media Sosial (Lanjutan)

\begin{tabular}{|c|c|c|c|}
\hline No & Aktivitas & \begin{tabular}{|c|} 
Strategi \\
\end{tabular} & \begin{tabular}{|c|} 
Deskripsi Strategi \\
\end{tabular} \\
\hline \multirow{3}{*}{2} & \multirow{3}{*}{$\begin{array}{l}\text { Transformasi merek } \\
\text { melalui media sosial. }\end{array}$} & \multirow{3}{*}{$\begin{array}{l}\text { Merubah persepsi } \\
\text { merek, struktur } \\
\text { perusahaan, dan cara } \\
\text { perusahaan } \\
\text { berkomunikasi di }\end{array}$} & Meninjau kemampuan dan prioritas media sosial. \\
\hline & & & $\begin{array}{l}\text { Menentukan penanggung jawab pengelola media } \\
\text { sosial. }\end{array}$ \\
\hline & & & $\begin{array}{l}\text { Meninjau kesadaran merek dan menetapkan } \\
\text { visi. }\end{array}$ \\
\hline \multirow{4}{*}{3} & \multirow{4}{*}{$\begin{array}{l}\text { Mendapatkan } \\
\text { pelanggan baru } \\
\text { menggunakan media } \\
\text { sosial. }\end{array}$} & \multirow{4}{*}{\begin{tabular}{|l|} 
\\
Menggunakan media \\
sosial untuk \\
meningkatkan prospek \\
calon pelanggan.
\end{tabular}} & $\begin{array}{l}\text { Menggunakan media sosial untuk menjangkau } \\
\text { calon pelanggan. }\end{array}$ \\
\hline & & & $\begin{array}{l}\text { Menggunakan konten media sosial untuk } \\
\text { mendorong interaksi. }\end{array}$ \\
\hline & & & $\begin{array}{l}\text { Meningkatkan konversi calon pelanggan menjadi } \\
\text { pelanggan. }\end{array}$ \\
\hline & & & $\begin{array}{l}\text { Mendorong pelanggan bertindak menjadi } \\
\text { pendukung bisnis melalui berbagi dan } \\
\text { rekomendasi. }\end{array}$ \\
\hline \multirow[t]{2}{*}{4} & \multirow{2}{*}{$\begin{array}{l}\text { Meningkatkan } \\
\text { penjualan ke pelanggan } \\
\text { yang sudah ada. }\end{array}$} & \multirow{2}{*}{$\begin{array}{l}\text { Menıngkatkan } \\
\text { penjualan yang } \\
\text { berfokus pada } \\
\text { pengembangan } \\
\text { strategi komunikasi } \\
\text { nelanogan }\end{array}$} & $\begin{array}{l}\text { Menggunakan media sosial untuk } \\
\text { mengkomunikasikan penawaran, konten } \\
\text { menarik, dan memberikan layanan. }\end{array}$ \\
\hline & & & $\begin{array}{l}\text { Meningkatkan ulasan di platform marketplace } \\
\text { menggunakan media sosial. }\end{array}$ \\
\hline \multirow{3}{*}{5} & \multirow{3}{*}{$\begin{array}{l}\text { Meningkatkan layanan } \\
\text { pelanggan melalui } \\
\text { pemasaran media } \\
\text { sosial. }\end{array}$} & \multirow{3}{*}{$\begin{array}{l}\text { Meningkatkan } \\
\text { layanan pelanggan } \\
\text { melalui media sosial. }\end{array}$} & $\begin{array}{l}\text { Mendengarakan untuk mengidentifikasi } \\
\text { pelanggan yang membutuhkan layanan. }\end{array}$ \\
\hline & & & $\begin{array}{l}\text { Berinteraksi untuk menjawab pertanyaan } \\
\text { pelanggan. }\end{array}$ \\
\hline & & & Mengelola layanan pelanggan perusahaan. \\
\hline
\end{tabular}

Tactics atau taktik merupakan alat yang memiliki urutan dari langkah-langkah taktis untuk mencapai tujuan perusahaan dan dibuat setelah strategi ditentukan. Taktik harus tetap fleksibel dan berorientasi jangka pendek sehingga dapat disesuaikan dengan situasi apa pun. Selain itu pada tahap ini dilakukan perancangan key performance indicator dan penentuan indicator menggunakan konsep balancedscorecard dari templat social media scorecard dan brand KPIs and strategy. Taktik pemasaran Facebook dapat dilihat pada Tabel 3 dan taktik pemasaran Instagram dapat dilihat pada Tabel 4. 
Tabel 3. Taktik Pemasaran Facebook

\begin{tabular}{|c|c|c|c|}
\hline No & Strategi & Taktik & Deskripsi Taktik \\
\hline \multirow{4}{*}{1} & \multirow{4}{*}{$\begin{array}{l}\text { Memahami penggunaan } \\
\text { media sosial. }\end{array}$} & \multirow{4}{*}{$\begin{array}{l}\text { Membuat halaman } \\
\text { dan optimasi halaman. }\end{array}$} & Menggunakan nama pengguna. \\
\hline & & & Menggunakan foto profil dan foto sampul. \\
\hline & & & Menulis dekripsi perusahaan dan produk. \\
\hline & & & $\begin{array}{l}\text { Mencantumkan info kontak dan situs pembelian } \\
\text { produk. }\end{array}$ \\
\hline \multirow{4}{*}{2} & \multirow{4}{*}{$\begin{array}{l}\text { Merubah persepsi } \\
\text { merek, struktur } \\
\text { perusahaan, dan cara } \\
\text { perusahaan } \\
\text { berkomunikasi di media } \\
\text { sosial. }\end{array}$} & \multirow{4}{*}{$\begin{array}{l}\text { Membuat konten } \\
\text { menarik. }\end{array}$} & Konten memiliki nilai instrinstik. \\
\hline & & & $\begin{array}{l}\text { Konten sesuai target pengguna Facebook sesuai } \\
\text { persona. }\end{array}$ \\
\hline & & & Konten berisi informasi dan penawaran produk. \\
\hline & & & Konten yang mendorong pengikut berinteraksi. \\
\hline \multirow[t]{2}{*}{3} & \multirow{2}{*}{$\begin{array}{l}\text { Menggunakan media } \\
\text { sosial untuk } \\
\text { meningkatkan prospek }\end{array}$} & \multirow{2}{*}{$\begin{array}{l}\text { Memanfaatkan } \\
\text { Facebook Ads. }\end{array}$} & $\begin{array}{l}\text { Memilih target pengguna Facebook sesuai } \\
\text { persona. }\end{array}$ \\
\hline & & & Mempersiapkan anggaran penggunaan iklan. \\
\hline
\end{tabular}

Tabel 3. Taktik Pemasaran Facebook (Lanjutan)

\begin{tabular}{|c|l|l|l|}
\hline No & \multicolumn{1}{|c|}{ Strategi } & \multicolumn{1}{c|}{ Taktik } & \multicolumn{1}{c|}{ Deskripsi Taktik } \\
\hline \multirow{2}{*}{4} & $\begin{array}{l}\text { Meningkatkan } \\
\text { penjualan yang } \\
\text { berfokus pada }\end{array}$ & $\begin{array}{l}\text { Mendorong pengikut } \\
\text { membeli produk di } \\
\text { platform }\end{array}$ & $\begin{array}{l}\text { Menulis deskripsi situs web perusahaan dan } \\
\text { kontak Whatsapp. }\end{array}$ \\
\cline { 3 - 4 } 5 & $\begin{array}{l}\text { Meningkatkan layanan } \\
\text { pelanggan melalui } \\
\text { media sosial. }\end{array}$ & $\begin{array}{l}\text { Berinteraksi di media deskripsi platform marketplace } . \\
\text { sosial. }\end{array}$ & $\begin{array}{l}\text { Memberika kontak costumer service } \text { untuk } \\
\text { pertanyaan lebih lanjut. }\end{array}$ \\
\cline { 4 - 4 } & \multicolumn{2}{|l}{ Menjawab komentar dan pertanyaan. } \\
\hline
\end{tabular}


Tabel 4. Taktik Pemasaran Instagram

\begin{tabular}{|c|c|c|c|}
\hline No & Strategi & Taktik & Deskripsi Taktik \\
\hline \multirow{4}{*}{1} & \multirow{4}{*}{$\begin{array}{l}\text { Memahami penggunaan } \\
\text { media sosial. }\end{array}$} & \multirow{4}{*}{$\begin{array}{l}\text { Membuat akun bisnis } \\
\text { dan optimasi akun. }\end{array}$} & Menggunakan nama pengguna. \\
\hline & & & Menulis deskripsi biografi akun. \\
\hline & & & Menggunakaan foto profil. \\
\hline & & & $\begin{array}{l}\text { Mencantumkan info kontak dan situs pembelian } \\
\text { produk. }\end{array}$ \\
\hline \multirow{8}{*}{2} & \multirow{8}{*}{$\begin{array}{l}\text { Merubah persepsi } \\
\text { merek, struktur } \\
\text { perusahaan, dan cara } \\
\text { perusahaan } \\
\text { berkomunikasi di media } \\
\text { sosial. }\end{array}$} & \multirow{8}{*}{$\begin{array}{l}\text { Membuat konten } \\
\text { menarik. }\end{array}$} & $\begin{array}{l}\text { Konten sesuai target pengguna Instagram sesua } \\
\text { persona. }\end{array}$ \\
\hline & & & Konten berisi informasi dan penawaran produk. \\
\hline & & & \begin{tabular}{|l|} 
Mengetahui jenis postingan. \\
\end{tabular} \\
\hline & & & Mengoptimasi feeds Instagram. \\
\hline & & & Memanfaatkan Instagram stories. \\
\hline & & & Membuat caption menarik. \\
\hline & & & Menggunakan hashtag untuk klasifikasi konten. \\
\hline & & & Posting ulang foto atau stories dari pelanggan. \\
\hline \multirow[t]{2}{*}{3} & \multirow{2}{*}{$\begin{array}{l}\text { Menggunakan media } \\
\text { sosial untuk } \\
\text { meningkatkan prospek }\end{array}$} & \multirow{2}{*}{$\begin{array}{l}\text { Memanfaatkan } \\
\text { InstagramAds. }\end{array}$} & $\begin{array}{l}\text { Memilih target pengguna Instagram sesuai } \\
\text { persona. }\end{array}$ \\
\hline & & & Mempersiapkan anggaran iklan. \\
\hline \multirow{3}{*}{4} & \multirow{3}{*}{$\begin{array}{l}\text { Meningkatkan } \\
\text { penjualan yang } \\
\text { berfokus pada } \\
\text { pengembangan strategi }\end{array}$} & \multirow{3}{*}{$\begin{array}{l}\text { Mendorong pengikut } \\
\text { membeli produk di } \\
\text { platform } \\
\text { marketplace. }\end{array}$} & Menulis deskripsi platform marketplace. \\
\hline & & & \begin{tabular}{|l} 
Menulis deskripsi platform marketplace. \\
\end{tabular} \\
\hline & & & $\begin{array}{l}\text { Menggunakan fitur swipe up yang } \\
\text { menhubungkan ke situs pembelian produk. }\end{array}$ \\
\hline \multirow[t]{2}{*}{5} & \multirow{2}{*}{$\begin{array}{l}\text { Meningkatkan layanan } \\
\text { pelanggan melalui } \\
\text { media sosial. }\end{array}$} & \multirow{2}{*}{$\begin{array}{l}\text { Berinteraksi di media } \\
\text { sosial. }\end{array}$} & $\begin{array}{l}\text { Memberika kontak costumer service untuk } \\
\text { pertanyaan lebih lanjut. }\end{array}$ \\
\hline & & & Menjawab komentar dan pertanyaan. \\
\hline
\end{tabular}

Action atau tindakan dilakukan untuk menjalankan langkah-langkah taktis pada rancangan strategi pemasaran media sosial. Tahap ini dilakukan pengelolaan pemasaran media sosial sehingga pengelolaan media sosial dapat terintegrasi dan pemasaran menjadi lebih efektif dan efisien. Tindakan pemasaran dilakukan dengan membagi deskripsi pekerjaan untuk setiap staf sehingga pemasaran media sosial lebih efektif. Pemasaran Facebook dan Instagram dilakukan sesuai penjadwalan konten yang sudah dibuat dan konten disesuaikan dengan taktik pemasaran setiap platform yang kemudian dilaksanakan selama enam bulan.

Control atau kontrol merupakan tahapan untuk mengukur dan mengevaluasi performa rancangan strategi pemasaran media sosial selama enam bulan dengan menggunakan aplikasi Keyhole.co. Berdasarkan hasil analisis Keyhole.co pemasaran Facebook memberikan jumlah total suka sebesar 1.776, total komentar sebesar 28, dan total engagement sebesar 1.804. Sedangkan pemasaran Instagram memberikan jumlah total suka sebesar 26.932, total komentar sebesar 637, dan total engagement sebesar 27.569. Tingkat keberhasilan strategi pemasaran media sosial dilihat dari key performance indicator berdasarkan kosep balanced scorecard dan diketahui bahwa perspektif finansial dan pelanggan dapat memenuhi target sedangkan perspektif proses internal dan pembelajaran dan pertumbuhan tidak memenuhi target. Key performance indicator dapat diliaht pada Tabel 5. 
Tabel 5. Key Performance Indicator

\begin{tabular}{|c|c|c|c|c|c|}
\hline \multirow{2}{*}{ Perspektif } & \multirow{2}{*}{ Key Performance Index } & Realisasi & Target & Pencapaian Target (\%) & \multirow{2}{*}{ Keterangan } \\
\hline & & (a) & (b) & (a:b) $\times 100 \%$ & \\
\hline \multirow{2}{*}{ Finansial } & $\begin{array}{l}\text { Persentase peningkatan penjualan produk di } \\
\text { marketpace. }\end{array}$ & 743 & 600 & 123,83 & Memenuhi Target \\
\hline & Persentase peningkatan pendapatan penjualan. & Rp409.430.000 & Rp250.000.000 & 163,77 & Memenuhi Target \\
\hline \multirow{2}{*}{ Pelanggan } & $\begin{array}{l}\text { Persentase peningkatan engagement media } \\
\text { sosial. }\end{array}$ & 29373 & 24000 & 122,39 & Memenuhi Target \\
\hline & $\begin{array}{l}\text { Persentase peningkatan nilai ulasan } \\
\text { marketplace. }\end{array}$ & 4,8 & 4,5 & 106,67 & Memenuhi Target \\
\hline \multirow{2}{*}{ Proses Internal } & Persentase kesesuaian posting konten. & 81 & 166 & 48,80 & Tidak Memenuhi Target \\
\hline & Persentase penghematan anggaran iklan. & Rp 2.500 .000 & $\begin{array}{|ll|}\operatorname{Rp} & 2.500 .000 \\
\end{array}$ & 100,00 & Tidak Memenuhi Target \\
\hline $\begin{array}{l}\text { Pembelajaran } \\
\text { dan Pertumbuhan }\end{array}$ & Persentase pelatihan pegawai & 1 & 2 & 50,00 & Tidak Memenuhi Target \\
\hline
\end{tabular}

Perhitungan pengembalian investasi dari penerapan rancanagn pemasaran media sosial dilakukan menggunakan return of investment social media atau pengembalian investasi media sosial. Pengembalian investasi dilakukan dengan membandingkan pendapatan sebesar Rp 1122.829.00 dan biaya yang dikeluarkan perusahaan sebesar Rp 60.600.000 untuk pemasaran media sosial selama enam bulan. Pengembalian investasi yang didapat perusahaan adalah sebesar $102,68 \%$ yang berarti saat mengimplementasi strategi pemasaran media sosial selama enam bulan $102,67 \%$ sehingga dapat dikatakan bahwa rancangan strategi pemasaran media sosial memberikan efek positif pada pendapan penjualan perusahaan.

Pembuktian untuk mengetahui perbedaan sgnifikan dari jumlah total engagement platform Facebook dan Instagram dilakukan dengan membandingkan data total engagement sebelum penerapan strategi (September 2019-Februari 2020) dan sesudah penerapan strategi (September 2020-Februari 2021) menggunakan uji hipotesis Wilcoxon signed-rank test yang dapat dilihat pada Tabel 6 .

Tabel 6. Data Uji Hipotesis Wilcoxon Signed-Rank Test

\begin{tabular}{|c|l|c|c|}
\hline \multirow{2}{*}{ No } & \multirow{2}{*}{ B ulan } & \multicolumn{2}{c|}{ Total Engagement } \\
\cline { 3 - 4 } & & Sebelum & Sesudah \\
\cline { 3 - 4 } & & $\left.\mathrm{X}_{1}\right)$ & $\left(\mathrm{X}_{2}\right)$ \\
\hline 1 & September & 1645 & 8154 \\
\hline 2 & Oktober & 2401 & 5518 \\
\hline 3 & November & 5287 & 5042 \\
\hline 4 & Desember & 2339 & 4874 \\
\hline 5 & Januari & 289 & 2733 \\
\hline 6 & Februari & 427 & 3052 \\
\hline
\end{tabular}

Data berdistibusi bebas dikarenakan waktu pengamatan selama enam bulan dan menghasilkan satu data per bulan. Tahapan uji hipotesis Wilcoxon signed-rank adalah sebagai berikut.

1. Hipotesis yang ditentukan dari uji hipotesis Wilcoxon signed-rank test adalah sebagai berikut.

- $\mathrm{H}_{0}: \mu 1=\mu 2$, maka nilai $\mu 2$ (setelah penerapan) tidak memiliki perbedaan yang signifikan dengan nilai $\mu 1$ (sebelum penerapan).

- $\mathrm{H}_{1:} \mu 1 \neq \mu 2$, maka nilai $\mu 2$ (setelah penerapan) memiliki perbedaan nilai yang sangat signifikan dengan nilai $\mu 1$ (sebelum penerapan). 
2. Taraf uji signifikansi $(\alpha)$ yang digunakan adalah 0.05 dikarenakan pemasaran media sosial termasuk jasa sehingga pengukuran efektifitas dan toleransi tidak ketat (Fischer, 1997). Penggunaan tabel nilai kritis Wilcoxon dikarenakan jumlah data (n) $<25$ sehingga tidak diperlukan perhitungan nilai $\mathrm{z}$ dan langsung membandingkan $\mathrm{T}_{\text {hitung }}$ dengan $\mathrm{T}_{\text {tabel. }}$. Taraf uji signifikansi adalah sebagai berikut.

- $\quad$ Nilai alpha $(\alpha) \quad=0.05$

- Jumlah data (n) $=6$

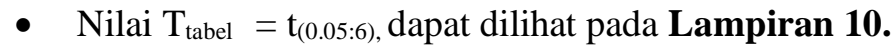

$$
=0
$$

3. Menentukan daerah keputusan.

Daerah keputusan untuk hipotesis adalah sebagai berikut.

- Apabila $\mathrm{T}_{\text {hitung }}<\mathrm{T}_{\text {tabel }}\left(\mathrm{H}_{0}\right.$ dapat diterima $)$.

- Apabila $\mathrm{T}_{\text {hitung }}>\mathrm{T}_{\text {tabel }}\left(\mathrm{H}_{0}\right.$ tidak dapat diterima $)$.

4. Perhitungan uji hipotesis Wilcoxon signed-rank test.

Perhitungan uji hipotesis Wilcoxon signed-rank test dilakukan berdasarkan data pendukung pada Tabel 6 dan rekapitulasi perhitungan selisih $\left(\mathrm{d}_{\mathrm{i}}\right)$ dapat dilihat pada Tabel 7.

Tabel 7. Perhitungan Selisih Uji Hipotesis Wilcoxon Signed-Rank Test

\begin{tabular}{|c|l|c|c|c|c|}
\hline \multirow{2}{*}{ No } & \multirow{2}{*}{ B ulan } & \multicolumn{2}{|c|}{ Total Engagement } & \multicolumn{2}{c|}{ Selisih } \\
\cline { 3 - 4 } & & Sebelum & Sesudah & \multirow{2}{*}{$(\mathbf{d i})$} & \multirow{2}{*}{$|\mathbf{d i}|$} \\
\cline { 3 - 4 } & $\left(\mathbf{X}_{\mathbf{1}}\right)$ & $\left(\mathbf{X}_{\mathbf{2}}\right)$ & & \\
\hline 1 & September & 1.645 & 8.154 & 6.509 & 6.509 \\
\hline 2 & Oktober & 2.401 & 5.518 & 3.117 & 3.117 \\
\hline 3 & November & 5.287 & 5.042 & -245 & 245 \\
\hline 4 & Desember & 2.339 & 4.874 & 2.535 & 2.535 \\
\hline 5 & Januari & 289 & 2.733 & 2.444 & 2.444 \\
\hline 6 & Februari & 427 & 3.052 & 2.625 & 2.625 \\
\hline
\end{tabular}

5. Menetapkan hasil perhitungan selisih $\left(\mathrm{d}_{\mathrm{i}}\right)$ menjadi bilangan mutlak $\left|\mathrm{d}_{\mathrm{i}}\right|$, kemudian memberi peringkat berdasarkan selisih $\left(\mathrm{d}_{\mathrm{i}}\right)$ terkecil sampai terbesar kemudian mengkelompokkan peringkat berdasarkan peringkat positif dan peringkat negatif. Rekapitulasi penetapan selisih $\left(\mathrm{d}_{\mathrm{i}}\right)$ menjadi mutlak $\mid \mathrm{d}_{\mathrm{i}}$, dan pengelompokkan peringkat dapat dilihat pada Tabel 8 .

Tabel 8. Penentuan Peringkat Uji Hipotesis Wilcoxon Signed-Rank Test

\begin{tabular}{|c|c|c|c|c|c|c|c|c|}
\hline \multirow{3}{*}{ No } & \multirow{3}{*}{ Bulan } & \multicolumn{2}{|c|}{ Total Engagement } & \multicolumn{2}{|c|}{ Selisih } & \multirow{3}{*}{ Pe ringkat } & \multirow{2}{*}{\multicolumn{2}{|c|}{$\begin{array}{r}\text { Kelompok } \\
\text { Peringkat } \\
\end{array}$}} \\
\hline & & \begin{tabular}{|l|} 
Se belum \\
\end{tabular} & Sesudah & \multirow{2}{*}{ (di) } & \multirow{2}{*}{ |di| } & & & \\
\hline & & $\left(\mathbf{X}_{1}\right)$ & $\left(\mathbf{X}_{2}\right)$ & & & & $(+)$ & $(-)$ \\
\hline 1 & September & 1645 & 8154 & 6509 & 6509 & 6 & 6 & \\
\hline 2 & Oktober & 2401 & 5518 & 3117 & 3117 & 5 & 5 & \\
\hline 3 & November & 5287 & 5042 & -245 & 245 & 1 & & 1 \\
\hline 4 & Desember & 2339 & 4874 & 2535 & 2535 & 3 & 3 & \\
\hline 5 & Januari & 289 & 2733 & 2444 & 2444 & 2 & 2 & \\
\hline 6 & Februari & 427 & 3052 & 2625 & 2625 & 4 & 4 & \\
\hline
\end{tabular}

6. Menghitung nilai terkecil (T) dari kelompok peringkat positif dan negatif. Formulasi untuk mengukur nilai terkecil (T) peringkat positif merujuk adalah sebagai berikut.

$$
\begin{aligned}
& \mathrm{T}=\text { Peringkat }_{\mathrm{n}}+\ldots \ldots \ldots+\text { Peringkat }_{\mathrm{n}} \\
& \mathrm{T}=6+5+3+2+4 \\
& \mathrm{~T}=20
\end{aligned}
$$


Sedangkan formulasi untuk mengukur nilai terkecil (T) peringkat negatif adalah sebagai berikut.

$$
\begin{aligned}
& \mathrm{T}=\text { Peringkat }_{\mathrm{n}}+\ldots \ldots \ldots+\text { Peringkat }_{\mathrm{n}} \\
& \mathrm{T}=1
\end{aligned}
$$

Nilai $\mathrm{T}_{\text {hitung }}$ adalah 1 dikarenakan nilai terkecil dari perbandingan kelompok peringkat positif dan negatif.

Hasil uji Wilcoxon membuktikan bahwa ada perbedaan signifikan dari jumlah total engagement dikarenakan $\mathrm{H}_{0}$ ditolak karena $\mathrm{T}_{\text {hitung }}(1)>\mathrm{T}_{\text {tabel }}(0)$ dan kurva penolakan dapa dilihat pada Gambar 2.

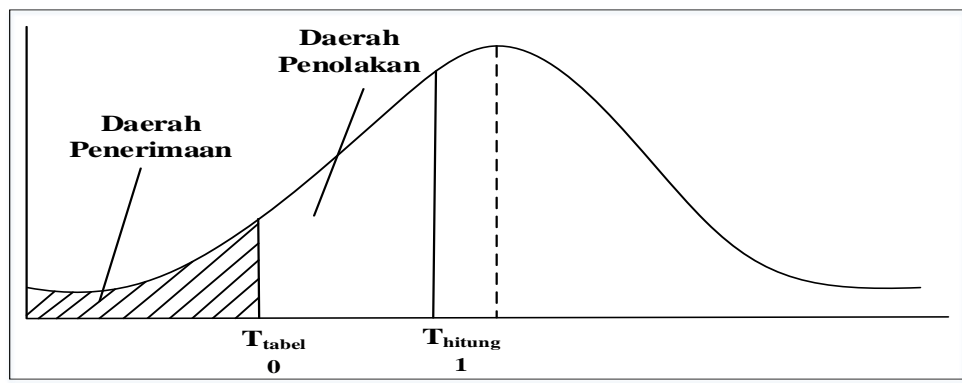

Gambar 2. Kurva Daerah Penolakan Uji Hiptesis Wilcoxon Signed-Rank Rest

Analisis performa strategi pemasaran media sosial dilakukan berdasarkan analisis aplikasi Keyhole.co pada aspek-aspek statistik yang terdiri dari tipe kiriman paling sering, tipe kiriman paling menarik, waktu kirim optimal, waktu kirim terbaik, panjang kiriman optimal, tagar teratas berdasarkan keterlibatan, dan tagar optimal. Berdasarkan hasil analisis platform Facebook dan Instagram aplikasi Keyhole.co dapat diketahui terdapat perbedaan dari aspekaspek statistik yang dapat dilihat pada Tabel 7.

\begin{tabular}{|c|c|c|c|c|c|}
\hline \multirow{2}{*}{ No } & \multirow{2}{*}{ Aspek } & \multicolumn{2}{|c|}{ Facebook } & \multicolumn{2}{|c|}{ Instagram } \\
\hline & & Deskripsi & Nilai Engagement & Deskripsi & Nilai Engagement \\
\hline 1 & $\begin{array}{l}\text { Tipe kiriman } \\
\text { paling sering }\end{array}$ & $\begin{array}{l}\text { Gambar atau } \\
\text { foto. }\end{array}$ & $124 \%$ & $\begin{array}{l}\text { Gambar atau } \\
\text { foto. }\end{array}$ & $65 \%$ \\
\hline 2 & $\begin{array}{l}\text { Kiriman paling } \\
\text { menarik }\end{array}$ & $\begin{array}{l}\text { Gambar atau } \\
\text { foto. }\end{array}$ & 124 & $\begin{array}{l}\text { Gambar atau } \\
\text { foto. }\end{array}$ & 404 \\
\hline \multirow{5}{*}{3} & \multirow{5}{*}{$\begin{array}{l}\text { Waktu kirim } \\
\text { optimal }\end{array}$} & Senin, 15.00 & & Senin, 15.00 & \\
\hline & & Rabu, 13.00 & & Selasa, 14.00 & \\
\hline & & Kamis, 09.00 & & Rabu, 15.00 & \\
\hline & & Jumat, 11.00 & & Jumat, 13.00 & \\
\hline & & Sabtu, 15.00 & & Sabtu 09.00 & \\
\hline 4 & $\begin{array}{l}\text { Panjang kiriman } \\
\text { optimal }\end{array}$ & $560-720$ kata & 142 & $281-560$ kata & 415 \\
\hline 5 & Tagar teratas & \#zs 190 & 151 & $\begin{array}{l}\text { \#mesin motor, } \\
\text { \#enginemotor, } \\
\text { \#mesin } 110 \mathrm{cc}\end{array}$ & 1.870 \\
\hline 6 & $\begin{array}{l}\text { Jumlah tagar } \\
\text { optimal }\end{array}$ & 1-2 tagar & 110 & $6-9$ tagar & 412 \\
\hline
\end{tabular}

Tabel 7. Analisis Keyhole.co Platform Facebook dan Instagram

\section{Kesimpulan}

Berdasarkan pembahasan dalam penelitian ini, dapat tarik beberapa kesimpulan sebagai berikut:

1. Perancangan strategi pemasaran media sosial dilakukan dengan menggunakan model SOSTAC. Situation analysis dilakukan dengan mengidentifikasi pelanggan, kompetitor, dan SWOT perusahaan. Objectives dilakukan dengan menetapkan tujuan pemasaran media sosial perusahaan yang teridiri dari sell, serve, speak, save, dan sizzle. Strategy dilakukan berdasarkan segmentasi, target, dan posisi perusahaan untuk menentukan 
strategi pemasaran media sosial. Taktics dilakukan dengan membuat detail strategi pemasaran media sosial. Action dilakukan dengan menjalankan strategi taktis yang sudah ditetapkan. Control dilakukan untuk mengevaluasi rancangan pemasaran media sosial. Penggunaan Keyhole.co dilakukan untuk menganalisis performa rancangan strategi pemasaran media sosial dan dapat digunakan sebagai dasar usulan perbaikan.

2. Faktor yang mempengaruhi kesadaran merek produk SND Racing dapat diketahui dari hal-hal yang mempengaruhi engagement pada platform media sosial. Faktor - faktor tersebut terdiri dari tipe kiriman paling sering, tipe kiriman paling menarik, waktu kirim optimal, waktu kirim terbaik, panjang kiriman optimal, tagar teratas berdasarkan keterlibatan, dan tagar optimal.

3. Penerapan rancangan strategi pemasaran media sosial dapat memberi peningkatan signifikan untuk jumlah total engagement platform Facebook dan Instagram sebesar 16.985 dibandingkan sebelum penerapan strategi pemasaran media sosial. Hal ini dibuktikan dengan pengujian hipotesis menggunakan uji hipotesis Wilcoxon signed-rank test dan diketahui bahwa terbukti ada perbedaan sebelum dan sesudah penerapan strategi pemasaran media sosial dikarenakan dikarenakan $\mathrm{H}_{0}$ ditolak $\left(\mathrm{T}_{\text {hitung }}(1)>\mathrm{T}_{\text {tabel }}(0)\right)$.

\section{Acknowledge}

Terima kasih kepada seluruh pihak yang terlibat dan memberi dukungan moril maupun material sehingga Tugas Akhir ini dapat diselesaikan sebagai syarat kelulusan memperoleh gelar Sarjana Teknik pada Program Studi Teknik Industri, Universitas Islam Bandung.

\section{Daftar Pustaka}

[1] Bernard, M., 2016. 25 Key Performance Indicator Yang Harus Diketahui. Jakarta: Flex Media Komputindo.

[2] Djamaludin., Aviasti., Rukmana, A., N., dan Rukmana, O., 2016. Peningkatan Kemampuan Usaha Kecil Menengah di Wilayah Bandung Raya Dalam Pemanfaatan Internet Sebagai Sarana Pemasaran dan Perluasan Jangkauan Pasar. [online] Tersedia pada: <https://ejournal.unisba.ac.id/index.php/ethos/article/view/1682> [Diakses 18 Januari 2021].

[3] Gunelius, dan Susan., 2011. 30 Minutes Social Media Marketing. USA: McGraw-Hill Companies.

[4] Kaplan., Robert., dan Norton, P., 1996. Balanced Scorecard. Jakarta: Erlangga.

[5] Smith, P. R., dan Chafey, D., 2017. Digital Marketing Excellence : Planning, Optimizing, and Integrated Online Marketing. New York: Kogan Page.

[6] Siegel., dan Sidney., 1992. Statistik Nonparametrik untuk Ilmu Sosial. Jakarta: Gramedia.

[7] Sutrisno., 2012. Manajemen Keuangan Teori, Konsep dan Aplikasi. Yogyakarta: EKONISIA. 